\title{
China and the World: Signaling Threat or Opportunities
}

\author{
Ran Peng \\ School of Public Policy, City University of Hong Kong, Tat Chee Avenue Kowloon Tong, Hong Kong. \\ Pr19874396@hotmail.com
}

\begin{abstract}
During the last decade, China seems much more active in global economic system and political fields than ever. The majority of the world's scholars believe that China's rise is inevitable. However, some countries advocate strongly the "China threat theory", which has bad effects on China's economy, political strategies and military power. This paper discussed both the positive and negative sides of China's rise, and mainly analyzed why China's rise actually provides more opportunities rather than threats. Through the studies of China's relationships with the United States, East Asian and African countries, and the opportunities China's economic policies provides, we found that China's rise could be peaceful and beneficial to the world. Furthermore, suggestions for Chinese government are given at the end of this paper.
\end{abstract}

Keywords: China threat; China's rise; international relation.

\section{Introduction}

Undoubtedly, the rise of China in recent years strongly attracts the world's attention and affects the power distributions among the world. Some Western scholars usually consider China as an ambitious country, which seeks for absolute powers. Many countries are worried about the tremendous growth of China's economy and military power. In recent years, many American scholars talk about the "China Threat" theory in front of the media. Yang and Liu (2012) points out, "The US did not begin to perceive China as a rising threat until the early 1990s when a few US government officials publicly accused China" [1]. In addition, many countries seem to believe in this theory. Policy makers start to concern about if China would rise peacefully or not. Breslin (2013) claims "It seems fairly clear that China wants to change its role in global politics, and that the emphasis on keeping a low international profile that informed Chinese policy from the 1980 s onwards is giving way to a more activist inclination" [2]. As China's interaction with the world increases, China's international image will be challenged more. The main reason is that China is a socialist country and Chinese culture is very different from Western countries. In addition, China's rapid growth makes the Third World countries worry about the possibility of readjustment of their relationships with China. In fact, many scholars doubt about China will still keep the "mutual benefits" promises, especially for African countries. Some people even argue that China is a neocolonialism country right now. These kinds of thoughts seem unavoidable. Undoubtedly, China's policy reforms are successful, which makes policy makers from other countries concerning about China's potential threats. What's more, AL-Rodhan (2007) claims that "The people's Republic of China is the most serious national security threat the United States" [3].

In addition to successful policies on economic reforms and military development, the majority of scholars are seriously concerning about the impacts of the Chinese economy on the world. Nowadays, the global economy is closely correlated which is known as the "global village". The growth of China's economy increases its "soft power". In fact, China has done a great job in dealing with global financial crisis. Since China joined the WTO, the Chinese economy plays a more and more important role in the world's economy. The China-ASEAN relations also become essential in East Asia. Although countries like the United States considers China as a competitor, China is still trying to show its friendliness to the world. Indeed, China's rise creates more opportunities than threats because it will benefit the world's economy and people in the long run. 


\section{The Possibility of the "China Threat Theory" and the Media Influences}

There has been a debate on China's political and economic powers. Many countries concern about China's capability in the future. A few countries have been thinking about the possibility of the "China Threat" theory. Indeed, the "China Threat" theory is based on the assumption that China develops its economy and military powers mainly for the purpose of dominating the world. However, just like many other countries, China has to build up and enhance its military force in order to protect its citizens. In other words, almost every country has to develop the hard power; China is not the only one. Also, many people should know that China was a victim of aggression in modern history. China is a country which supports freedom and peace, but it has to make sure its citizens are protected from foreign aggression due to historical experiences. In fact, in recent hundred years, China has never invaded any countries. Even in nowadays, Confucianism is still the mainstream philosophical ideas, which actually encourage peaceful development.

As a developing country, China needs to spend more money and time on the progress of its economy and military force. Looking though the world's history, many developed countries have done the same. Moreover, Chinese political leaders implement several strategies and policies to show their kindness to the world, such as the "win-win" strategy and the "Five Principles of Peaceful Coexistence". In other words, China's primary goal is developing its economy. China does not have any intentions to threat any countries.

Moreover, the "China Threat" theory firstly comes out from the United States. Undoubtedly, media in the United States plays an important role. Yang and Liu found that the news media shapes public opinion and government policy through some critical ways, such as the media coverage can influence the relative salience of a particular foreign issue and can influence how the general public and policy makers think about the issue. As a result, both policy makers and ordinary citizens are worried about China's rise is way too much due to the exaggerative reports from the American media. In fact, such worries may turn out to be unnecessary, and China may not be a threat at all. Up until this moment, China hasn't done anything to threat any countries.

\section{China's Relationships with the United States, East Asian and African Countries}

Nowadays, China has a better relationship with the United States comparing to the past because of economic interactions, such as the FDI. In fact, the United States has been investing in China for many years. Since China joined the WTO, it attracts foreign investment to come in and both China and the other countries achieved benefits from these investments. In fact, China is considered one of the largest suppliers and consumers in the world. Chow (2010) shows that China has become the second largest export countries since 2007 [4]. In fact, no one would refuse to cooperate with China including the United States due to China's tremendous market. For example, as a labour intensive country, China produces and exports cheap manufacturing goods, while the United States imports these goods and exports hightech products to China. By doing this, the United States has surplus each year. Chow found that the US had a trade surplus with China of 2.7 billion in 1980. In other words, the United States is better-off by allocating most of its labour in high-tech industry because it has comparative advantage in producing high-tech products. It is the best strategy for making money because labour is much more expensive in America. This can indirectly prove China's "win-win" strategy.

Unfortunately, some East Asian and African countries argue that China dominates the world's labourintensive manufacture industry and somewhat hurts their benefits. Shafaeddin (2006) claims that China's export structure is similar to that of the Republic of Korea and Malaysia in the final market for a number of 'finished' capital goods. Thailand, India, Vietnam, Pakistan and Nepal also have similar export structure with China [5]. In fact, China wants to accelerate its process of industrialization, so it's inevitable to compete with other manufacturing-based economies. The world market can be considered a big pie, while China gets the bigger piece of it; the remaining part for other manufacturing-based 
economies becomes smaller. However, this is only one part of the story. On the contrary, China cooperates with other Asian and African countries for mutual benefits. For example, China proposed the FTA, which is a "Free Trade Agreement" between China and ten ASEAN members. Also, China increases its foreign direct investment (FDI) in many Asian and African countries in recent years. When China invests in these countries, it creates a lot of job opportunities for local people and eventually accelerates the development of these countries. For example, China builds railways in Africa, which definitely facilitates African people's daily life. More convenient transportation also has a positive impact on business and trade. In addition, Chinese-owned companies usually provide higher salaries compared to African companies, which indeed improve some local African employees' quality of life. Furthermore, China is still in transition period, which means massive changes and possibilities. In other words, China will eventually shift its economy from manufacturing-based to other industry. Therefore, African and East Asian countries don't have to worry about China is taking over their business. Indeed, China has been providing necessary assistance for the development of many Third World Countries.

\section{China's Economic Policies Provides Opportunities to the World}

The rapid development of China definitely leads to more opportunities than threats because its policies are designed based on the purpose of achieving mutual benefits. There are some major economic policies pushes the Chinese economy growing dramatically. There first one is called the "Open-door" policy. China's open door policies came into effect since 1985. The implementation of the "Open-door" policy encourages both foreign direct investments and local business investments. This can be considered as a signal that China's primary goal is developing the economy as soon as possible. In fact, the policy was very successful. The Chinese economy has been boosting dramatically since the year 1985 . As we found from the earlier study, the export as a share of GDP rose from 9.1 percent in 1985 to 37.8 percent in 2008. As Chinese economy grows dramatically, both local and foreign investments make a huge amount of profits, which encourage more consecutive investments and eventually make the economy growing even faster. In addition, foreign investments in coastal areas usually receive extra benefits from the tax deduction policy. The most famous one is the establishment of the "Special Economic Zones", including Shenzhen, Xiamen, Zhuhai and Shantou. In fact, foreign companies earn a huge amount of money from their investments in these "Special Economic Zones". Chinese government also uses monetary policy and fiscal policy to adjust the economic development when necessary. China also builds a lot of infrastructure, such as railways and highways in Africa and East Asia. The construction of the newest high speed railway will be completed in 2018 which will make the cost of transportation fees decrease sharply. Although Chinese government achieves profits from its investment in these projects, African countries which cannot afford the costs of railway projects can also receive more benefits. This is another example of the "win-win" situation, which implies the friendliness and harmlessness of China's rise.

Moreover, some countries believe that the Chinese Communist Party's socialist values are very different from the capitalist values. Therefore, China's rise and success indirectly disprove the superiority of the capitalist system. However, neither the socialist system nor the capitalist system is perfect, so adapting socialist or capitalist system doesn't necessarily determine whether a country can succeed or not. In fact, there are successful as well as unsuccessful socialist and capitalist countries in the world. Another important policy the Chinese Communist Party (CCP) adapting is the "Dual-track system", which combines planed and market economy together. Because of the absolute control of the CCP and its correct policies, China can survive and succeed after several economic recessions. The whole world also benefits from the success of the Chinese economy. If Western people can accept multiculturalism, they should be able to accept the success of the Chinese economy rather than fear about it. 


\section{Discussion}

China has done a great job in its economy development. The Chinese should keep up their good jobs because China will definitely face more and more challenges during the process of further development. Without a strong economy, China cannot maintain its international status and may lose in future competition. Sometimes, soft power plays an important role than other factors. Therefore, a strong economy will definitely attract more business partners.

In addition, there are some notable issues and potential risks which the Chinese government should concern about during economic development. For example, continuously rapid economic development may lead to a "bubble economy" based on previous experiences. A "bubble economy" is usually caused by a rapid increase in commodity and housing price. When the rapid increase in housing price contributes to most of the so-called economic growth, the prosperous economy is full of bubbles. Nowadays, housing price in China, especially in large cities has been increasing rapidly, but the wages didn't increase that much. Previous experiences show that when most people cannot afford the housing price, the economy may face the danger of recession.

Another issue is the appreciation of RMB (the Chinese currency). In recent decade, Chinese goods become more and more popular in the world due to its high cost-performance. Since these Made-inChina products are very popular in the global market, the United States wants to convince the Chinese government to increase the RMB/USD exchange rate. When RMB appreciates, for the same amount of Chinese goods, importers have to pay more, which means Chinese products would become less competitive in the global market. Although the appreciation of RMB somewhat reflects China's success and makes Chinese people (the currency holders) richer, it's not a good sign. In fact, Japan also faced the same situation in the 90s. At that time, Japan was experiencing economic miracle as well, the United States forces the Japanese government to increase the YEN/USD ratio. As a result, the Japanese economy collapses for more than 10 years until now. The Chinese government should learn from this lesson and maintain RMB at a relatively stable exchange rate. If the Chinese currency appreciates too much, Chinese goods will no longer be able to attract that many international consumers. In other words, the demand for Chinese goods will decrease and the Chinese government will lose money.

The Chinese government should understand why the "China Threat" theory emerges and know how to solve it effectively. Sometimes, the United States just uses this theory to accuse China in order to get benefits. Although China emphasizes "mutual benefits", some of the American scholars don't buy that story. Therefore, China should just focus on its development and good actions are always more powerful than words. When China keeps helping other countries and developing itself, the reputation of China will certainly have improvement. In international relation, only strong countries such as the United States have the power of judgement. In other words, the justice usually depends on who has the power rather than who is right. In fact, China is a friendly country. If China becomes powerful, the world would be more peaceful.

\section{Conclusion}

China has the potentials to replace the United States and become the most powerful country in the world. The United States fears about the rise of China, so the "China Threat" theory emerges. However, this theory won't stand up through debates. In fact, China is one of the friendliest countries in the world. China's rise not only benefits Chinese citizens, but also benefits many developing countries. However, the Chinese government should keep up their good work and prepare for further challenges during the development process. What's more the Chinese government should concern about potential issues such as hyperinflation and learn from the experiences of other developed countries. And China also needs to pay more attention to the creating of good international image though media, while state image is the most important intangible assets of any sovereign states and media is a main constructor of it. 


\section{References}

[1]. Yi Edward Yang, Xinsheng Liu. The 'China Threat' through the Lens of US Print Media: 19922006[J]. Journal of Contemporary China, 2012, 21(76):695-711.

[2]. $\dagger$ S B. China and the global order: signaling threat or friendship. [J]. International Affairs, 2013, 89(3):615-634.

[3]. Al-Rodhan K R. A Review of the China Threat Theory: A Systematic Analysis [J]. Asian Perspective, 2007, 31(3):41-66.

[4]. Chow D. China's Response to the Global Financial Crisis: Implications for U.S.-China Economic Relations [J]. Global Bus.1.rev, 2010.

[5]. Shafaeddin S M. Is China's accession to WTO threatening exports of developing countries. [J]. International Journal of Systematic \& Evolutionary Microbiology, 2006, 56(Pt 1):145-150. 